\title{
ТРАНСФОРМАЦІЇ СУЧАСНОЇ АУДІОВІЗУАЛЬНОЇ КУЛЬТУРИ В КОНТЕКСТІ НАУКОВИХ ГУМАНІТАРНИХ КОНЦЕПЦІЙ
}

\author{
- Желєзняк Серафим Володимирович \\ - Аспірант, \\ ORCID: 0000-0002-9430-0527, e-mail: tritonische@gmail.com, \\ Київський національний університет культури і мистецтв, \\ вул. Є. Коновальця, 36, Київ, Україна, 01133
}

\section{- Для цитування:}

Желєзняк, С.В. (2021). Трансфрормації сучасної аудіовізуальної культури в контексті наукових гуманітарних концепцій. Питання культурології, (38), 76-84. doi: https://doi. org/10.31866/2410-1311.38.2021.245704.

\section{Анотація}

Мета статті - виявити актуальні концепції авторів, що досліджують сучасну аудіовізуальну культуру, аби усвідомити загальні засади їі функціонування, розкрити особливості компонентів та зумовленість станом сучасного суспільства. Методологія дослідження. Під час розгляду предмета дослідження були використані загальнонаукові методи: порівняльний - зіставлялися та порівнювалися погляди різних науковців щодо суспільних процесів сьогодення та місця аудіовізуальної культури в них для більш об'ємного та об'єктивного висвітлення досліджуваного явища; методи аналізу і синтезу — предмет розкладався на компоненти та здійснювалося їхнє вивчення окремо задля того, аби наприкінці розвідки сучасна аудіовізуальна культура розглядалася як багатомірне суспільне явище; історичний - для простеження концепцій авторів щодо еволюції екранної культури та її засад. Наукова новизна статті пояснюється вивченням з нового погляду сучасної аудіовізуальної галузі як невіддільного елементу культури, засновуючись на думці українських та закордонних науковців. Висновки. У статті проаналізовано підходи авторів до вивчення культурних та екранних процесів задля висвітлення особливостей існування аудіовізуальної культури в сучасному суспільстві. Розглянуто концепції щодо телебачення та його ролі в соціумі, еволюції різних видів екранного дійства та їхні зв'язки з розвитком людини, а також запропоновано зв'язок сучасного звукового супроводу з такими поглядами на сутність кіно. Окрім цього, розкрито наукову думку щодо специфіки використання звукового елементу аудіовізуальних творів у сучасному контексті та зв'язок екранної культури з технологіями з культурних та мистецьких позицій. Також були досліджені наукові підходи до сучасних суспільних процесів як до контексту функціонування аудіовізуальної сфери.

Ключові слова: екранна культура; сучасна аудіовізуальна культура; звук; кіно; телебачення; мультимедіа 


\section{- Вступ}

Одне із найпоширеніших явищ у сучасному суспільстві, з яким люди взаємодіють майже на усіх етапах свого життя - аудіовізуальна культура. Така іiї поширеність вимагає особливого усвідомлення цього феномена та вивчення аудіовізуальної культури з різних поглядів. Дослідження сучасної культури в царині аудіовізуального прагне пояснити передумови, основи цього явища, взаємозв'язок з іншими елементами суспільного життя, розкрити подальші перспективи.

Вивчення аудіовізуальної культури в контексті розвитку культури періодично з'являється в дослідженнях українських та закордонних науковців. В українській науці питання екранної культури досліджується доволі ретельно. Слід звернути увагу на дисертації, що присвячені подібній тематиці. 3. Алфьорова (2008) розглядає аудіовізуальну галузь, здійснюючи аналіз місця категорії візуального в культурі та ін. Важливі чинники та принципи функціонування аудіовізуальної культури досліджують у своїх публікаціях В. Скуратівський (2020), Г. Чміль (2020) та багато інших авторів. Робота В. Кулика (2010) зосереджена на дискурсі екранних медіа та їхній ролі у суспільстві. Розуміння сучасного стану культури висвітлено в роботах I. Петрової (Petrova, 2020), О. Павлової (Pavlova, 2021) та ін. Серед робіт І. Петрової (Petrova, 2020) варто виокремити статтю «Метамодернізм як культурологічна концепція», в якій аналізуються сучасні процеси в культурі, їхні особливості та сутність, а також недоліки з погляду ідеї метамодернізму.

Варта розгляду перша частина каталогу авторства О. Литвинової (2009) «Музика в кінематографрі України», в якій детально викладена інформація про композиторів в українських кінострічках за всю історію існування кіно, зокрема у фрільмах сучасного періоду, а також наведено аналіз сучасних процесів, пов'язаних з екранною культурою України. Така праця дає уявлення про великий перелік українських екранних робіт, а також про творчих професіоналів, що працювали з музикою у цих роботах, як вагомої частини аудіовізуальної культури.

\section{- Мета статті}

Мета статті полягає у виявленні актуальних досліджень сучасної аудіовізуальної культури, демонстрації теоретичних концепцій вивчення екранної культури та ії компонентів задля ширшого розуміння властивостей, принципів фрункціонування такого явища, що зумовлене процесами у сучасному суспільстві.

\section{- Виклад матеріалу дослідження}

Сучасна аудіовізуальна культура є дуже складним явищем та містить безліч можливостей для її дослідження. Складність такого предмета вивчення виявляється, зокрема, у тому, що в ньому містяться багато компонентів, а саме в контексті поняття «екранна культура» можуть розглядатися кіно, телебачення, мультимедіа та ін., а також наведену характеристику явища, що аналізується, зумовлює значна інтеграція аудіовізуальної культури у різноманітні види діяльності суспільства. 
Ґрунтовним дослідженням сучасних українських екранних мистецтв $€$ праця В. Кулика (2010) «Дискурс українських медій: ідентичності, ідеології, владні стосунки». У ній автор зосереджується на особливостях масмедіа, принципах їхнього фрункціонування, роль дискурсу та мови у роботі засобів масової комунікації, впливу та взаємодії медіа з їхніми глядачами та споживачами. Дослідник детально аналізує українські приклади роботи різних ЗМК, а також їхній внесок та інтеграцію у формування ідеологічних та політичних процесів.

Повноцінний розгляд аудіовізуальної культури також потребує вивчення ширшого контексту процесів у сучасному суспільстві. Для цієї статті становлять інтерес матеріали міжнародної наукової конференції, що проводилася у Київському національному університеті імені Тараса Шевченка «Дні науки філософського факультету - 2021». У збірнику матеріалів до зазначеної конференції є секція із тезами доповідей, що присвячені візуальним дослідженням, мистецькій та культурній проблематиці. Однією з актуальних публікацій для цієї роботи є теза О. Павлової (Pavlova, 2021) «Проблема очевидності мистецтва в ситуації "естетичного буму"». О. Павлова у цій праці зосереджується на питаннях специфріки мистецтва та естетичних переживань у сучасній культурі. Дослідниця окреслює зміну ролі мистецтва в суспільстві, певне підпорядкування художньої творчості логіці споживання. Також у роботі наголошується, що мистецтво поступово перетворюється на технологію та втрачає свою унікальність. Утім, О. Павлова полемізує щодо того, чи варто вважати такі трансформації процесами деградації культури і мистецтва. Авторка вказує, що такий рух може призвести до утворення суспільства почуттів.

Для розуміння специфіки аудіовізуальної культури також важливим $є$ поняття образу. Г. Бьом (Boehm, 2012) у своїй праці використовує термін «image» (з англ. - зображення, образ) та аналізує його роль і значення для створення, відображення присутності певного відсутнього об'єкта. Також дослідник стверджує, що сучасна культура використовує зображення, образ для того, аби зменшити обсяги такої відсутності. Українська науковиця О. Павлова (2019) у статті «Homo Pictor та культурна практика образу в концепції Готфріда Бьома» ретельно вивчає концепцію Г. Бьома та наголошує, зокрема, на формуванні проблеми образу як культурної практики (с. 10).

В. Скуратівський (2020) досліджує сутність та витоки кінематографра і телебачення з погляду розвитку людства та культури. Автор ґрунтує свою думку на працях інших науковців та зазначає, що кіно пов'язане з тим моментом, коли первісне суспільство побачило та усвідомило навколишній світ, об'єкти, що містяться в ньому. На думку вченого, враження від спостереження людей за середовищем пізніше з'являються в описах пейзажів у літературі, у подібному жанрі в живописі, а також у кіно. Зрештою, В. Скуратівський вказує, що екранні твори $€$ відображенням взаємодії раннього суспільства зі світом. Серед іншого науковець поєднує технології в кіно, а саме панорамний екран (циркораму), з особливостями тогочасного сприйняття людиною навколишнього середовища.

Варто також зауважити, що сучасна аудіовізуальна культура пов'язана з технологіями та їхнім розвитком. Процес появи екранних мистецтв, а також методи виготовлення творів аудіовізуальної культури мають взаємодію та певну залеж- 
ність від технологічних розробок та винаходів. Шлях створення кіно, телевізійної програми та ін. покладається на технічні інструменти, що вдосконалюються впродовж історії існування та розвитку цієї галузі. Також і нині під час виробництва та показу екранних робіт активно використовується технічний інструментарій. Такий стан культури та суспільства певним чином нагадує концепції у праці О. Шпенглера (Spengler, 1980) «Занепад Європи», в якій науковець розмірковував про період у розвитку культур, що пов'язаний із сильною роллю цивілізації у ньому. Зазначений дослідник розглядав процес ходу та зміни життя культур від їхньої появи до зникнення. Культуролог аналізував різні етапи в існуванні людських суспільств та запропонував свій підхід до цієї проблеми, системи періодів культур. Зокрема О. Шпенглер, як відомо, зауважував, що поява цивілізації зазвичай характерна для останнього етапу у житті культури.

Над дослідженням впливу технологій на аудіовізуальні твори, зокрема на їхні художні та естетичні характеристики, працювала українська авторка І. Зубавіна та інші науковці. І. Зубавіна (2011) серед іншого аналізувала взаємодію цифрових технологій та утворення часопростору у кінострічці.

Використання технологій в аудіовізуальній культурі впливають і виявляються не тільки під час роботи із зображальною частиною твору, але також під час взаємодії зі звуковим супроводом. Звук - рівноправний елемент в аудіовізуальних творах, тому варто йому також приділити увагу. Слід зауважити, що об'ємний звук за дією та розміщенням у просторі схожий на зображення, що знаходиться навколо глядача, і, можливо, відповідає раннім людським враженням від взаємодії зі світом. Ц. Цвєткова (Tsvetkova, 2020) у тезах доповіді «Об’ємний звук у документальному фільмі» розглядає переваги та можливі труднощі під час використання багатоканального звуку у документальних кінотворах. Авторка посилається на закордонних авторів і аналізує питання відмінності об'ємного звуку в ігровому та неігровому кіно. Дослідниця зауважує, що застосування такої звукової доріжки може розширити художні можливості творців документальних фрільмів, проте згадує про небезпеку втрати достовірності аудіовізуальної роботи за умови невдалого використання підходів з ігрового кіно під час створення фронограми.

В. Скуратівський (2020) далі розмірковує про становлення телебачення та передумови появи цього явища. Український науковець аналізує цей процес і зауважує, що сутність цього виду екранної культури зумовлена використанням копіювання, тиражування певної інформації в суспільстві в певний період. Дослідник наголошує, що така технологія і підхід до розповсюдження інформації, творів з'явилися у Новий час, і раніше не були доступні через негативне ставлення до копіювання у традиційній культурі. Автор стверджує, що на шляху появи телебачення були такі способи репродукування інформації, як літографія, фотографія та ін.

3. Алфьорова (2008) у дисертації зосереджується на культурологічних засадах розвитку візуальної культури кінця XX - початку XXI ст. Дослідниця докладно розглядає концепції різних науковців щодо аудіовізуальних медіа, а саме телебачення, кінематографра, мережі Інтернет. Авторка розкриває питання масової культури, зокрема у площині візуального, а також приділяє увагу тран- 
сфрормаціям суспільства. Надто науковиця окреслює перехід до субкультур як важливого елементу сучасного соціуму. 3. Алфьорова до того ж аналізує дослідження візуальної масової культури, вплив ЗМІ на фрормування інфрормаційного складника у суспільстві. Під час вивчення такої проблематики авторка робить висновок, що культурологічні концепції дають змогу розглянути сучасну культуру, зокрема візуальні процеси, проте 3. Алфьорова підкреслює необхідність розгляду мистецьких творів у контексті культурологічних підходів.

Сучасну українську художню культуру також висвітлює у дисертації українська дослідниця Т. Боднарчук (2009). Авторка розмірковує про неї з позицій постмодернізму. Окрім цього в праці проаналізовані основні характеристики цього етапу розвитку культури, що зумовлює певні мистецькі прояви. Науковиця вказує на широту явища постмодернізму та необхідність розуміння його не тільки як мистецького прояву, а і як певного світогляду та стану суспільства. Т. Боднарчук загалом зосереджується на українській літературі, театрі та музичному мистецтві й прикладах взаємодії постмодернізму з творами різних авторів.

Серед українських науковців, які досліджують сучасну культуру, процеси, що характерні для неї, принципи, що пов'язані з протіканням таких процесів, також варто зазначити І. Петрову. У вказаній вище роботі авторка здійснює детальний виклад позицій іншої світоглядної парадигми - метамодерну як стану культури сьогодення. Необхідно звернути увагу на аналіз цієї концепції, її сутність та еволюцію, аби краще розуміти місце сучасної аудіовізуальної культури та принципи й ідеї, що можуть бути в її основі. Слід зазначити, що існування одночасно декількох дискурсів ускладнюють протікання буття екранної культури та взаємодії ії̈ з людьми (Petrova, 2020).

Більш детально таку взаємодію вивчає Г. Чміль (2020) у своїй праці «Людина - екран: візуальна антропологія (пост)сучасності». Авторка зазначає важливість екрана у соціумі, його вплив на напрями досліджень та на життя загалом. Дослідниця зауважує, що екран має взаємопротилежні ознаки та можливості. Вони виявляються у тому, що аудіовізуальний твір може демонструвати, передавати життя та явища, що існують в ньому, а також може каталізувати створення нових рухів та процесів у суспільстві (Чміль, 2020, с. 143).

Г. Чміль аналізує фрілософські погляди на сучасну культуру і їхній зв'язок із аудіовізуальною, екранною культурою. Зокрема, у роботі звертається до концепцій різних закордонних авторів та розглядає питання, пов'язане з ідеологією, що присутня в суспільстві та аудіовізуальній культурі. Дослідниця наводить висновок про сутність екрана як особливого культурного явища, топосу, яке вміщує в собі складний зв'язок фантазій, наративу як змісту екранних творів, і зазначає: «Якщо позначати цей “топос" саме як специфічну форму реальності, то слід визнати, що така реальність $€$ історично унікальним явищем. А сучасні дигітальні медіатехнології, які дозволяють нескінченно максимізувати візуалізацію всіх мислимих і немислимих аспектів нашого буття, лише інтенсифікують та розширюють простір цього віртуального світу, розгортаючи навколо людини інтенсивну "реальнісну гру"». (Чміль, 2020, с. 151-152).

Отже, звертаючись до думок авторки, можна зробити висновок, що аудіовізуальна культура є важливим інструментом для трансляції життя суспільства, 
сенсів, ідей, що присутні у ньому, у культурі певної спільноти. Проте водночас екранні твори можуть впливати на людей та формувати культурні процеси, трансформації, що обумовлює необхідність детального вивчення аудіовізуальної галузі й надалі.

\section{- Висновки}

У роботі розглянуто широкий спектр концепцій, що висвітлюють існування аудіовізуальної культури в контексті сучасного суспільства. Завдяки цьому була здійснена спроба охопити принципи, характеристики сучасної екранної культури. Зазначено підходи та думки щодо ролі медіа в суспільстві, засад розвитку кіно і телебачення з огляду на історичні передумови формування взаємозв'язків людини, світу, технічних засобів. Розкрито підхід до вивчення місця звукового ряду у творах кіно, висвітлено особливості окремих видів аудіовізуальної культури, а також наведено деякі концепції науковців щодо ситуації сучасної культури, зокрема змін у мистецькому полі, взаємовпливу людини та екрана тощо. Підсумовуючи, варто зазначити, що проблематика аудіовізуальної культури потребує подальших комплексних міждисциплінарних досліджень для кращого розуміння ролі та змісту сучасної екранної культури в суспільстві.

\section{- Список використаних джерел}

Алфьорова, 3. І. (2008). Візуальне мистецтво кінця XX - початку XXI століття [Дисертація доктора мистецтвознавства, Харківська державна академія культури].

Боднарчук, Т.В.(2009). Постмодерністські тенденції у сучасному українському мистецтві [Дисертація кандидата мистецтвознавства, Львівська національна музична академія. ім. М. В. Лисенка].

Зубавіна, І. Б. (2011). Художнє моделювання часопростору в кінематографрі [Дисертація доктора мистецтвознавства, Інститут проблем сучасного мистецтва Національної академії мистецтв України].

Кулик, В. (2010). Дискурс українських медій: ідентичності, ідеології, владні стосунки [Монографія]. Критика.

Литвинова, О. У. (2009). Музика в кінематографрі України: Каталог (Ч. 1: Автори музики художньо-ігрових фільмів, які створювалися на кіностудіях України). Логос.

Павлова, О. Ю. (2019). Ноmo Pictor та культурна практика образу в концепції Готфріда Бьома. Вісник Національної академії керівних кадрів культури і мистецтв, 3, 8-14.

Скуратівський, В. (2020). Скуратівський у КINO-КОЛI (1997-2008). Інститут культурології НАМ України.

Чміль, Г.П. (2020). Людина - екран: візуальна антропологія (пост)сучасності [Монографрія]. Інститут культурології НАМ України.

Boehm, G. (2012). Representation, Presentation, Presence: Tracing the Homo Pictor. In J. C. Alexander, D. Bartmanski, \& B. Giesen (Eds.), Iconic Power: Materiality and Meaning in Social Life (pp. 15-23). Palgrave Macmillan.

Pavlova, O. (2021, April 21-22). The Problem of Art's Obviousness in the Situation of "Aesthetic Boom". In A. Konverskyi (Ed.), The Days of Science of the Faculty of Philosophy - 
2020, International Scientific Conference (pp. 450-453). Publishing center "Kyiv University".

Petrova, I. (2020). Metamodernism as a Concept of Cultural Studies. Issues in Cultural Studies, (36), 14-23. doi: 10.31866/2410-1311.36.2020.221039

Spengler, O. (1980). The Decline of the West (C. F. Atkinson, Trans.; Vol. 1: Form and Actuality; $2^{\text {nd }}$ ed.). Alfred A. Knopf. (Original work published January 1, 1926).

Tsvetkova, T. (2020). Surround Sound in Documentary Film. Proceedings of University of Ruse, 59(6.3), 71-75.

\section{- References}

Alforova, Z. I. (2008). Vizualne mystetstvo kintsia XX - pochatku XXI stolittia [Visual Art of the End of the $20^{\text {th }}$ - the Beginning of the $21^{\text {st }}$ Century] [Doctor's thesis, Kharkiv State Academy of Culture] [in Ukrainian].

Bodnarchuk, T. V. (2009). Postmodernistski tendentsii u suchasnomu ukrainskomu mystetstvi [Postmodernist Tendencies in Contemporary Ukrainian Art]. [Candidate's thesis, Lviv National Music Academy named after M. V. Lysenko] [in Ukrainian].

Boehm, G. (2012). Representation, Presentation, Presence: Tracing the Homo Pictor. In J. C. Alexander, D. Bartmanski, \& B. Giesen (Eds.), Iconic Power: Materiality and Meaning in Social Life (pp. 15-23). Palgrave Macmillan [in English].

Chmil, H. P. (2020). Liudyna - ekran: vizualna antropolohiia (post)suchasnosti [Human Being - Screen: Visual Anthropology of (Post)modernity] [Monograph]. Institute for Cultural Researchof the National Academy of Arts of Ukraine [in Ukrainian].

Kulyk, V. (2010). Dyskurs ukrainskykh medii: identychnosti, ideolohii, vladni stosunky [Discourse of Ukrainian Media: Identities, Ideologies, Power Relations] [Monograph]. Krytyka [in Ukrainian].

Lytvynova, O. (2009). Muzyka v kinematohrafi Ukrainy [Music in the Cinema of Ukraine]: Catalog. (Pt. 1: Avtory muzyky khudozhno-ihrovykh filmiv, yaki stvoriuvalysia na kinostudiiakh Ukrainy [Authors of Music of Feature Films Created at Film Studios of Ukraine]). Lohos [in Ukrainian].

Pavlova, O. (2021, April 21-22). The Problem of Art's Obviousness in the Situation of "Aesthetic Boom". In A. Konverskyi (Ed.), The Days of Science of the Faculty of Philosophy 2020, International Scientific Conference (pp. 450-453). Publishing centre "Kyiv University" [in English].

Pavlova, O. Yu. (2019). Homo Pictor ta kulturna praktyka obrazu v kontseptsii Hotfrida Boma [Homo Pictor and cultural practice of image in the concept of Gottfried Boehm]. National Academy of Managerial Staff of Culture and Arts Herald, 3, 8-14 [in Ukrainian].

Petrova, I. (2020). Metamodernism as a Concept of Cultural Studies. Issues in Cultural Studies, (36), 14-23. doi: 10.31866/2410-1311.36.2020.2210399 [in English].

Skurativskyi, V. (2020). Skurativskyi u KINO-KOLI (1997-2008) [Skurativskyi in KINO-KOLO (1997-2008)]. Institute for Cultural Researchof the National Academy of Arts of Ukraine [in Ukrainian].

Spengler, O. (1980). The Decline of the West (C. F. Atkinson, Trans.; Vol. 1: Form and Actuality; $2^{\text {nd }}$ ed.). Alfred A. Knopf. (Original work published January 1, 1926) [in English].

Tsvetkova, T. (2020). Surround Sound in Documentary Film. Proceedings of University of Ruse, 59(6.3), 71-75 [in English]. 
Zubavina, I. B. (2011). Khudozhnie Modeliuvannia Chasoprostoru v Kinematohrafi [Artistic Modelling of Space-time in Cinema] [Doctor's thesis, Modern Art Research Institute National Academy of Arts of Ukraine] [in Ukrainian].

\section{TRANSFORMATIONS OF MODERN AUDIOVISUAL CULTURE IN THE CONTEXT OF SCIENTIFIC CONCEPTS IN HUMANITIES}

\section{- Serafym Zheliezniak}

- PhD student, ORCID: 0000-0002-9430-0527, e-mail: tritonische@gmail.com, Kyiv National University of Culture and Arts, Kyiv, Ukraine

\section{- Abstract}

The purpose of the article is to identify current concepts of authors who study contemporary audiovisual culture to understand the general principles of its functioning; to reveal the features of its components and the conditionality by modern society. Research methodology. Considering the subject of research, the general scientific method was used: comparative method is to compare the views of different scientists on the social processes of today and the place of audiovisual culture in it to cover the studied phenomenon more voluminously and objectively; methods of analysis and synthesis are to componentise and study separately, so that modern audiovisual culture is considered as a multidimensional social phenomenon at the end of the research; the historical method is to trace the authors' conceptions of the evolution of screen culture and its principles. The scientific novelty of the article is explained by studying the modern audiovisual industry as an integral element of culture from a new point of view, based on the views of Ukrainian and foreign scholars. Conclusions. The article analyses the authors' approaches to cultural and screen processes to highlight the features of audiovisual culture in modern society. The article considers the concepts of television and its role in society, the evolution of different types of screen action and their connection with human development, as well as the connection of modern sound with such views on the essence of cinema. In addition, the scientific opinion on the specifics of the use of the sound element of audiovisual works in the modern context and the connection of screen culture with technology from a cultural and artistic standpoint is revealed. Scientific approaches to modern social processes as a context of the functioning of the audiovisual sphere were also studied.

- Keywords: screen culture; contemporary audiovisual culture; sound; cinema; television; multimedia 


\title{
- ТРАНСФОРМАЦИИ СОВРЕМЕННОЙ АУДИОВИЗУАЛЬНОЙ КУЛЬТУРЫ В КОНТЕКСТЕ НАУЧНЫХ ГУМАНИТАРНЫХ КОНЦЕПЦИЙ
}

\author{
- Железняк Серафим Владимирович \\ - Аспирант, \\ ORCID: 0000-0002-9430-0527, e-mail: tritonische@gmail.com, \\ Киевский национальный университет культуры и искусств, \\ Киев, Украина
}

\section{- Аннотация}

Цель статьи - выявить актуальные концепции авторов, исследующих современную аудиовизуальную культуру, чтобы осознать общие принципы ее функционирования, раскрыть особенности компонентов и обусловленность состоянием современного общества. Методология исследования. При рассмотрении предмета исследования были использованы общенаучные методы: сравнительный - сопоставлялись и сравнивались взгляды разных ученых относительно общественных процессов действительности и места аудиовизуальной культуры в них для более объемного и объективного освещения исследуемого явления; методы анализа и синтеза - предмет разлагался на компоненты и осуществлялось их изучение отдельно для того, чтобы в конце исследования современная аудиовизуальная культура рассматривалась как многомерное общественное явление; исторический - для прослеживания концепций авторов относительно эволюции экранной культуры и ее основ. Научная новизна статьи объясняется изучением с новой точки зрения современной аудиовизуальной отрасли как неотделимого элемента культуры, основываясь на взглядах украинских и зарубежных ученых. Выводы. В статье проанализированы подходы авторов к изучению культурных и экранных процессов для освещения особенностей существования аудиовизуальной культуры в современном обществе. Рассмотрены концепции относительно телевидения и его роли в социуме, эволюции различных видов экранного действа и их связи с развитием человека, а также предложена связь современного звукового сопровождения с такими взглядами на сущность кино. Кроме этого, раскрыта научная мысль о специфике использования звукового элемента аудиовизуальных произведений в современном контексте и связь экранной культуры с технологиями с культурных и художественных позиций. Также были исследованы научные подходы к современным общественным процессам как к контексту функционирования аудиовизуальной сферы.

Ключевые слова: экранная культура; современная аудиовизуальная культура; звук; кино; телевидение; мультимедиа 